\title{
Industry 4.0 technologies and manufacturing back-shoring: a European perspective
}

\author{
Luciano Fratocchi ${ }^{1}$, Cristina Di Stefano ${ }^{1}$ \\ ${ }^{1}$ University of L'Aquila, Department of Industrial and Information Engineering and Economics, L'Aquila, Italy
}

\section{ABSTRACT}

Over the last two decades, companies have increasingly been re-evaluating their off-shoring strategies and implementing decisions on relocations of second degree (RSD). In some cases, the RSD decision has been implemented through back-shoring. The topic has attracted the attention of several scholars, some of whom have specifically investigated the role of Industry 4.0 technologies in the backshoring decision-making process. This paper aims to shed new light on the role that Industry 4.0 technologies play as a driver or an enabling factor for companies that are evaluating RSD alternatives. A two-step explorative approach has been used for this research. In the first step, a theoretical approach has been followed by developing a structured literature review based on 115 Scopus-indexed journal articles. The second step of the methodology is based on the empirical evidence of European countries using the UnivAQ manufacturing reshoring dataset. The collected data provides evidence of the growing interest of scholars in this issue; however, attention has mainly been focused on two single technologies, production automation and additive manufacturing. The empirical data offers interesting findings in terms of industry and geographic characterisation.

\section{Section: RESEARCH PAPER}

Keywords: reshoring; Industry 4.0; manufacturing,

Citation: Luciano Fratocchi, Cristina Di Stefano, Industry 4.0 technologies and manufacturing back-shoring: a European perspective, Acta IMEKO, vol. 9, no. 4, article 3, December 2020, identifier: IMEKO-ACTA-09 (2020)-04-03

Section Editor: Leopoldo Angrisani, University of Naples Federico II, Italy

Received October 11, 2019; In final form August 7, 2020; Published December 2020

Copyright: This is an open-access article distributed under the terms of the Creative Commons Attribution 3.0 License, which permits unrestricted use, distribution, and reproduction in any medium, provided the original author and source are credited.

Corresponding author: Luciano Fratocchi, e-mail: luciano.fratocchi@univaq.it

\section{INTRODUCTION}

Manufacturing activities have been off-shored (and, often, also out-sourced) for a long time. Such location decisions have been motivated primarily by efficiency seeking, and they have therefore generally involved low-cost countries (e.g. Eastern Europe and Asia). However, in the last two decades, companies have been increasingly re-evaluating their previous off-shoring decisions having encountered several off-shoring pitfalls [1]. As a consequence, they have implemented decisions on relocations of second degree (RSD) [2], also referred to as reshoring [3], that consist of the relocation of manufacturing activities either to the home country (relocation to the home country [RHC] or backshoring) or to another host country (relocation to a third country [RTC]). In the case of RTC, the relocation may be either to a new host country in the home region (near-shoring) or to a far-away host country (further off-shoring) [3], [4]. We recognise the term 'reshoring' has often been adopted with very different meanings, ranging from the 'generic change of location with respect to a previous off-shore country' [3] to the relocation to the home country [5], [6]. However, in this paper, we use the term reshoring to refer to a generic RSD decision that is, independently of the governance mode (in- vs out-sourcing), adopted to manage relocated manufacturing activities. We also recognise that the term 'near-shoring' has been adopted to refer to the initial off-shoring in countries located in a company's home region [5]. However, in this paper, we use the term nearshoring to refer to an RSD in a second host country located in a company's home region.

Among the three RSD alternatives (back-shoring, nearshoring and further off-shoring), RHC has attracted the attention of several scholars over the last ten years [7]-[9]. More specifically, the phenomenon has been investigated in-depth from the perspective of motivations, i.e. drivers that induce companies to revise their initial off-shoring decisions. Among such motivations, a growing relevance has been assumed of the adoption of automated production systems (see, for instance, [10], [11]) and additive manufacturing [12]-[14]. Both these production technologies are included in the set of Industry 4.0 technologies, i.e. those based on cyber physical systems, which 
include 'smart machines, warehousing systems and production facilities that have been developed digitally and feature end-toend ICT-based integration, from inbound logistics to production, marketing, outbound logistics and service' [15].

In the international business literature, it is widely recognised that information and communication technologies (ICTs) may have a relevant impact on the company's internationalisation since they allow for remote coordination, extending the span of control and reducing its cost [16]-[18]. Moreover, such technologies permit companies to 'fine slice' their value-adding activities and to locate their production in different places, as in the 'global factory' scenario [19], [20]. However, technologies embedded in Industry 4.0 may also promote a reconfiguration of the company production footprint, since they increase a company's productivity [21], [22], which, in turn, weakens (if not eliminates) the location advantages of low cost countries [10], [11], [23]. At the same time, Industry-4.0-enabling technologies support a higher level of flexibility in manufacturing processes, allowing companies to be more responsive to clients' needs and to offer them customised products [10]-[14], [23], [24]. In this respect, it is worth noting that the influence (if any) of Industry 4.0 technologies on back-shoring decisions has been increasingly proposed as a future research avenue (e.g. [7], [9], [25], [26]). Therefore, it is time to define the state of the current academic debate on Industry 4.0 technologies and second-degree relocations to the home country. Consequently, this paper is based on the following research questions:

a) Does Industry 4.0 represent a driver/motivation [27]-[28] for companies that are evaluating RSD alternatives?

b) Does Industry 4.0 represent an enabling factor [26], [28] for companies that are evaluating RSD alternatives?

The paper aims to shed new light on this issue, adopting an explorative approach based on a variety of data sources. More specifically, a two-step explorative research method will be used. In the first step, a theoretical approach is followed by developing a structured literature review based on 115 Elsevier Scopusindexed journal articles published before August 2019. The second step of the paper methodology is based on empirical evidence from the UnivAQ manufacturing reshoring dataset (UMRD), which has already been adopted in previous backshoring research [10]-[13], [29]-[31], since it is recognised as the most comprehensive set of data at a global level. Since Industry 4.0 phenomenon may have dissimilarities among different geographic areas, attention has been focused on reshoring evidence from European countries.

Findings obtained from the two-step methodology described earlier provide evidence of the growing interest of scholars in the impact of Industry 4.0 enabling technologies on manufacturing reshoring decisions. However, attention has primarily focused on two single technologies, production automation (42 out of 115 sampled Elsevier Scopus-indexed journal articles, published between 2014 and 2019) and additive manufacturing (10 documents published in the last two years). Moreover, only four journal articles (of which three were published in 2019) specifically investigated the causality (if any) of Industry 4.0 technologies on back-shoring. However, the research findings emerging from these four articles are quite differentiated and not definitive. Finally, it is worth noting that, while the majority of sampled articles conceptualise Industry 4.0 technologies as a driver [7], these technologies have also been viewed as an enabling factor [26], [28].

The paper is structured in three sections, the first of which describes the two-step methodology adopted. In the following section, findings obtained through the chosen methodology are presented and discussed. Finally, the third section contains conclusions, implications and limitations.

\section{METHODOLOGY}

As outlined above, in order to examine the investigated research questions, a two-step explorative methodology has been applied. The first one is based on a structured literature review, e.g. 'a systematic, explicit, and reproducible design for identifying, evaluating, and interpreting the existing body of recorded documents' [32] regarding back-shoring decisions. It has been performed according to the process model for content analysis described by [33], which has already been adopted to conduct literature reviews on back-shoring [7], [9]. Attention has been focused on Elsevier Scopus-indexed journal articles published before August 2019. This source has been chosen since it is widely recognised as one of the top business and management databases [34]. The following research criteria have been adopted:

a) English language

b) publication date before August 2019 (although no limits have been applied for the starting date given the novelty of the investigated phenomenon)

c) containing at least one of the following sets of terms in the title, abstract and/or keywords: "reshor*", "re-shor*", "backshore*", "back-shor*", "back-reshor*" and "back-sourc*",

We found a total number of 177 journal articles. After all the co-authors had carefully read the full text of these articles, the following excluding criteria were adopted:

- journal articles focusing on the back-shoring of companies operating in industries not related to manufacturing (e.g. ICT companies)

- documents published in sources without peer review systems

- journal articles in which the searched terms are used to indicate a different concept from the one of interest (for instance, some of the keywords belonging to the reshoring concept are used with different meanings in the maritime and building engineering research fields)

- documents referring to functions other than operations (e.g. human resources and research and development [R\&D]).

Based on these criteria, 62 documents were eliminated; therefore, the total number of sampled documents was 115 .

The second step of the methodology is based on empirical evidence from the UMRD dataset that contains data from the Uni-CLUB MoRe reshoring dataset, already adopted for use in the research on manufacturing back-shoring (see, among others, [4], [10]-[13], [27], [29]-[31]), and the European Reshoring Monitor dataset by the EU foundation, Eurofound, used in several recent studies [11], [30], [31].

Up to the end of December 2018, the UMRD dataset contained a total of 1,279 instances of evidence regarding backshoring decisions implemented at the global level. Among them, 814 are related to RSD decisions implemented by European companies.

\section{FINDINGS}

\subsection{Findings from the extant literature}

An analysis of the 115 sampled journal articles clearly shows that the relationship (if any) between Industry 4.0 technologies as a whole and back-shoring has been addressed by only four 
journal articles (namely, [10], [11], [23], [35]). However, wider attention has been given to some specific Industry 4.0 technologies, including automation and three dimension (3D) printing/additive manufacturing (Table 1). More specifically, reshoring scholars have been increasingly conceptualising automation as a back-shoring driver and/or an enabling factor since 2014. In the sampled literature, we found a total of 42 documents referring to this issue. In contrast, attention on the role of additive manufacturing/3D printing technologies has only arisen in the last two years (2018 and 2019). This finding may be at least partially explained by the infancy of the additive manufacturing technologies [12], [13]. Finally, one contribution [10] specifically refers to another two Industry 4.0 technologies, sensors and simulation. At the same time, [11] investigated the opportunity for adopting cyber physical systems to connect production and development and/or buyers and suppliers.

As far as production automation technology is concerned, the first evidence in the sampled journal articles is proposed by [36], who found that $47.5 \%$ of Danish companies that off-shored production activities between 2009 and 2014 found the same activities could be back-shored as a result of the advances in automation. Similarly, [37] and [38] found, in a sample of Danish, Finnish and Swedish companies, that access to technology (including production automation) is one of the 'significantly more important drivers for back-shoring than for off-shoring $(p \leq 0.001)^{\prime}$ [38]. Moreover, [39] and [40] found, on the basis of a Swedish sample, that companies that had both off- and backshored during the investigated period considered access to technology to be of a slightly lower level of importance than companies implementing only back-shoring strategies. Finally, in their qualitative study, [28] found that several companies decided to back-shore in Sweden due to the benefits offered by production automation. However, the huge contribution of such an enabling technology to the relocation of manufacturing activities in the home Nordic countries seems to be questioned by scholars who investigated other geographic areas. For instance, [10] point out that only $13.6 \%$ of the 840 back-shoring decisions made by the EU and US companies they analysed specifically declared at least one of the Industry 4.0 technologies as a relocation driver. At the same time, [41] found that robotics has a negative impact on off-shoring decisions (at least for companies located in developed countries), but it does not yet trigger back-shoring decisions.

Production automation has usually been seen as a driver for relocation to the home country since it reduces labour costs and increases productivity [42]. This, in turn, 'makes it more viable to produce in high cost environments' [26]. Another benefit offered by production automation is regarding the reduction of costs in order to implement a flexible production system [43], allowing companies to customise products for different customers' targets and, in turn, improve companies' responsiveness [14]. Based on this, [10] state that production automation may support two types of back-reshoring strategy: 'cost-oriented' (i.e. relocation aimed at reducing production and logistics costs) and 'flexibilityoriented' (aimed at improving a company's responsiveness to customer needs).

This evidence is quite relevant since, according to these two authors, the two typologies of reshoring decisions are the most diffused among the 840 global-level back-reshoring initiatives they analysed. In contrast, 'quality-oriented' back-shoring strategies, i.e. when the relocation to the home country is aimed at implementing product upgrade strategies [44], are less relevant. This finding is quite at odds with the previous evidence collected
Table 1. Breakdown of sample articles by year and article content.

A Published articles; B Production automation; C Additive manufacturing; D Sensor; E Simulation; F Cyber physical systems; G Industry 4.0 impact on back-shoring

\begin{tabular}{cccccccc}
\hline Year & A & B & C & D & E & F & G \\
\hline 2007 & 1 & & & & & & \\
2009 & 1 & & & & & & \\
2011 & 1 & & & & & & \\
2012 & 1 & & & & & & \\
2013 & 6 & & & & & & \\
2014 & 11 & 3 & & & & & \\
2015 & 8 & 1 & & & & & \\
2016 & 23 & 12 & & & & & \\
2017 & 16 & 6 & & & & & \\
2018 & 24 & 13 & 8 & & & 1 & \\
2019 & 23 & 7 & 2 & 1 & 1 & & 3 \\
Total & 115 & 42 & 10 & 1 & 1 & 1 & 4 \\
\hline
\end{tabular}

by [10] and [24] with respect to UK back-shoring companies. A final question on the role of automation in back-shoring decisions is that posed by the research of [26]: "if the level of automation should be seen as a factor acting as a barrier or driver', i.e. if it either boosts the back-shoring decision or its lack hinders a relocation to the home country.

As far as the $3 \mathrm{D} /$ additive manufacturing technologies are concerned, it is expected they will have a disruptive impact on global value chains (GVC), thereby also supporting back-shoring decisions [45], [46]. In this respect, it is worth noting that [14] found that $72 \%$ of the 50 companies investigated that were adopting additive manufacturing technologies positively evaluated the contribution it makes to back-shoring decisions. In addition, [47] states that 3D printing technologies will induce firms to locate manufacturing activities closer to customers; hence, its adoption would boost reshoring decisions. However, [10] adopt a more restrictive position, stating that this technology may support the implementation of only quality-oriented backshoring decisions.

Additive manufacturing better supports product development processes and the integration of $\mathrm{R} \& \mathrm{D}$, design, production and marketing functions [22]. Moreover, additive manufacturing allows companies to reduce prototyping costs and times [11]. In addition, [14] state that relocation to the home country is boosted by the following six benefits that additive manufacturing technologies offer in terms of supply chain management: 'shorter lead time, responsiveness to the product and market changes, lower transportation costs, fewer miscommunications with suppliers, more customization options, fewer products stored in inventory'. At the same time, [12] and [13] present evidence that the technical and economic benefits provided by 3D printing represent an adequate response to several of the back-shoring drivers discussed in the extant literature [7]. Furthermore, [12] and [13] showed that industries in which additive manufacturing technologies are implemented are generally the same ones in which earlier empirical research found evidence of back-shoring strategies. This finding completes the previous evidence presented by [48], who classified manufacturing industries according to their propensity to adopt additive manufacturing technologies.

As already noted, the attention paid by scholars to the relationship (if any), and even the causality, between manufacturing reshoring and the whole set of Industry 4.0 
technologies is still in its infancy. Among the few authors who have investigated such a linkage, [10] point out that 'robotics is not a necessary ingredient of [back-] reshoring', but 'Industry 4.0 supports manufacturing [back-] reshoring when design and product innovation are involved'. At the same time, [11] provide evidence that, at least until now, back-shoring decisions have been implemented without investing in new technologies, especially if the relocation was aimed at leveraging the 'made in' effect and/or shortening the lead time and improving the company's responsiveness. However, authors expect Industry 4.0 may, in the near future, play a specific role in supporting manufacturing relocation decisions, especially in the case of skill shortages, due to the previous de-industrialisation emerging after decades of manufacturing off-shoring and/or when companies aim to improve design and strengthen product-development linkages. These findings are also confirmed by [35], who analysed a sample of Danish manufacturing companies. They found that the investigated technologies had no impact on the decision to relocate manufacturing activities to the home country. In contrast, [23] found a positive and significant association between investments in Industry 4.0 technologies and backshoring decisions.

Moreover, their study, which focused on manufacturing companies in Germany, Austria and Switzerland, shows that there is no causality between the two variables since both are driven by the research on higher levels of flexibility. It is worth noting that a previous investigation into a German sample conducted by [49] found that Industry 4.0 technologies played a role in supporting back-shoring decisions in only 13 of the 50 sampled back-shoring decisions they analysed. Furthermore, the relationship between the two issues was not adequately corroborated by a quantitative analysis, since the mean value was below 3 on a Likert scale from 1 to 5 (specifically, 2.3 for companies implementing relocation to the home country coupled with in-sourcing, and 2.2 for those that out-sourced reshored production activities). Findings by [49] also show that the adoption of the investigated technologies is mainly related to companies declaring the following back-shoring drivers: innovation, testing of technologies and time-to-market reduction. Of specific note is the [23] study in which the authors point out that the higher level of responsiveness allowed by Industry 4.0 technologies may be carefully evaluated in terms of the geographical distribution of a company's customers. More specifically, if company customers are located in countries/regions other than the home country, the adoption of Industry 4.0 technologies would induce companies to implement RTC strategies, either in the form of near-shoring or of further off-shoring.

To sum up, the structured literature review conducted offers a varied set of results that are not conclusive. While several authors recognise that individual Industry 4.0 technologies (mainly 3D/additive manufacturing and automation) may have an impact on manufacturing relocation decisions, their impact is highly dependent on the strategic aims pursued by the company. Moreover, analyses have been focused, until now, on a restricted number of countries, mainly in Europe. Therefore, further investigations are required; in this respect, evidence belonging to the UMRD, which will be discussed in the next section, may contribute to the academic debate.

\subsection{Empirical findings}

Given the lack of homogeneity in the results emerging from the extant literature and in order to investigate more deeply the
Table 2. Breakdown of back-shoring decisions by host region. Source: UMRD.

\begin{tabular}{|c|c|}
\hline Host region/country & Decisions \\
\hline China & $33.8 \%$ \\
\hline Asia (other than China) & $9.2 \%$ \\
\hline Asia (not specified) & $2.2 \%$ \\
\hline Asia & $45.2 \%$ \\
\hline Eastern Europe \& former USSR & $17.6 \%$ \\
\hline Western Europe & $26.0 \%$ \\
\hline Europe (not specified) & $0.5 \%$ \\
\hline Europe \& former USSR & $44.1 \%$ \\
\hline North Africa \& Middle East & $3.7 \%$ \\
\hline South Africa & $0.1 \%$ \\
\hline Africa (not specified) & $0.2 \%$ \\
\hline Africa & $4.1 \%$ \\
\hline North America & $2.4 \%$ \\
\hline Central \& South America & $1.5 \%$ \\
\hline Americas & $3.8 \%$ \\
\hline Oceania & $0.1 \%$ \\
\hline Not available & $2.7 \%$ \\
\hline Total & $100.0 \%$ \\
\hline
\end{tabular}

proposed research question, attention is now focused on the empirical evidence collected from the UMRD. It contains secondary data belonging to back-shoring decisions implemented by companies at a global level. However, for the aims of this paper, attention has been focused on companies headquartered in Europe. Up to December 2018, the UMRD contains a total of 814 examples of back-shoring decisions implemented by companies headquartered in 24 European countries. Companies have been taking and implementing such decisions since the 1990s, but most of the examples are from this century. Before analysing the impact (if any) of Industry 4.0 technologies on back-shoring decisions, it seems useful to point out the main characteristics of the sampled back-shoring decisions.

As far as the geographical dimension (host country/region) is concerned, the evidence is homogeneously divided between Asia and Europe (Table 2). This finding is quite interesting and may be, at least partially, explained by the 'region-centric' approach often adopted by European companies when off-shoring their production activities. These location strategies were given a strong boost by the European Union enlargements in 2004 and 2007 , which generated an opportunity to produce in low-cost countries close to Western Europe. Finally, it is worth noting that the majority of intra-Europe relocations have been implemented among Western countries, i.e. between high-cost nations. This evidence seems to confirm the idea that production offshoring has not been aimed only at reducing production costs.

The breakdown by company size shows that half of the backshoring decisions have been implemented by large companies. The other half is divided equally between medium and small and micro companies (Table 4).

The equal distribution in terms of company size is consistent with some previous findings [9], [27], [50]. However, it must be acknowledged that the data related to Germany [23], [51], [52] and the Scandinavian countries [38]-[40] shows a higher backshoring propensity among large companies. 
Table 4. Breakdown of back-shoring decisions by company size. Source: UMRD.

\begin{tabular}{lc}
\hline \multicolumn{1}{c}{ Company size } & Decisions \\
\hline Large & $52.2 \%$ \\
Medium & $23.6 \%$ \\
Small \& Micro & $23.2 \%$ \\
Not available & $1.0 \%$ \\
Total & $100.0 \%$ \\
\hline
\end{tabular}

The breakdown by industry (Table 3) shows that at least one back-shoring decision has been implemented in 24 different sectors. The industries with the highest representation (more than $10 \%$ ) are the 'Manufacture of machinery and equipment not elsewhere classified', the 'Manufacture of leather and related products' and the 'Manufacture of computer, electronic and optical products'. Therefore, it seems the intensity of an industry's technology is not relevant.

When considering the back-shoring drivers (Table 5), three out of the four most cited belong to the 'Customer perceived values' quadrants of the [27] framework: 'Customer responsiveness improvement' (17.1\%), 'Made in effect' (19.5\% of total sample) and 'Delivery time' (17.3\%). 'Logistics costs'

Table 3. Breakdown of back-shoring decisions by industry. Source: UMRD.

\begin{tabular}{|c|c|c|}
\hline $\begin{array}{l}\text { NACE } \\
\text { code }\end{array}$ & Description & Decisions \\
\hline 28 & $\begin{array}{l}\text { Manufacture of machinery and equipment not } \\
\text { elsewhere classified }\end{array}$ & $10.6 \%$ \\
\hline 15 & Manufacture of leather and related products & $10.6 \%$ \\
\hline 26 & $\begin{array}{l}\text { Manufacture of computer, electronic and optical } \\
\text { products }\end{array}$ & $10.1 \%$ \\
\hline 14 & Manufacture of apparel & $9.8 \%$ \\
\hline 27 & Manufacture of electrical equipment & $9.6 \%$ \\
\hline 32 & Other manufacturing & $6.6 \%$ \\
\hline 10 & Manufacture of food products & $6.0 \%$ \\
\hline 30 & Manufacture of other transport equipment & $5.9 \%$ \\
\hline 25 & $\begin{array}{l}\text { Manufacture of fabricated metal products, except } \\
\text { machinery and equipment }\end{array}$ & $5.2 \%$ \\
\hline 29 & $\begin{array}{l}\text { Manufacture of motor vehicles, trailers and semi- } \\
\text { trailers }\end{array}$ & $4.8 \%$ \\
\hline 22 & Manufacture of rubber and plastic products & $4.5 \%$ \\
\hline 31 & Manufacture of furniture & $3.3 \%$ \\
\hline 20 & Manufacture of chemicals and chemical products & $2.3 \%$ \\
\hline 21 & $\begin{array}{l}\text { Manufacture of basic pharmaceutical products and } \\
\text { pharmaceutical preparations }\end{array}$ & $2.3 \%$ \\
\hline 24 & Manufacture of basic metals & $2.0 \%$ \\
\hline 13 & Manufacture of textiles & $1.8 \%$ \\
\hline 23 & $\begin{array}{l}\text { Manufacture of other non-metallic mineral } \\
\text { products }\end{array}$ & $1.2 \%$ \\
\hline 17 & Manufacture of paper and paper products & $1.0 \%$ \\
\hline 16 & $\begin{array}{l}\text { Manufacture of wood and of products of wood and } \\
\text { cork, except furniture }\end{array}$ & $0.6 \%$ \\
\hline 11 & Manufacture of beverages & $0.6 \%$ \\
\hline 18 & Printing and reproduction of recorded media & $0.6 \%$ \\
\hline 12 & Manufacture of tobacco products & $0.1 \%$ \\
\hline 33 & $\begin{array}{l}\text { Repair and installation of machinery and } \\
\text { equipment }\end{array}$ & $0.1 \%$ \\
\hline 62 & $\begin{array}{l}\text { Computer programming, consultancy and related } \\
\text { activities }\end{array}$ & $0.1 \%$ \\
\hline \multicolumn{2}{|c|}{ Not available } & $0.1 \%$ \\
\hline \multicolumn{2}{|l|}{ Total } & $100.0 \%$ \\
\hline
\end{tabular}

$(16.3 \%)$ belong to the cost quadrant. Therefore, back-shoring decisions seem to be aimed more at effectiveness than at efficiency. This finding is relevant to the theoretical positions found in the extant literature (e.g. [10]).

It is worth noting that researchers have not yet conducted an analysis aimed at investigating the most relevant contingency factors (e.g. company size, geographic location, motivations) that characterise the back-shoring companies. Future research should investigate this issue, which could offer useful insights.

Table 5. Breakdown of back-shoring decisions by declared motivation. Motivations declared by at least 10 companies. Motivations belonging to Industry 4.0 in bold. Source: UMRD.

\begin{tabular}{|c|c|}
\hline Motivation & Decisions \\
\hline Made in effect (home country) & $19.5 \%$ \\
\hline Company's organisational restructuring & $17.6 \%$ \\
\hline Delivery time (including delays) & $17.3 \%$ \\
\hline $\begin{array}{l}\text { Customer responsiveness/vicinity - higher service } \\
\text { quality }\end{array}$ & $17.1 \%$ \\
\hline Logistics costs (including freight costs) & $16.3 \%$ \\
\hline Off-shored poor product quality & $16.1 \%$ \\
\hline $\begin{array}{l}\text { Adoption of automation and/or other innovative } \\
\text { product/process technologies (excluding 3D } \\
\text { printing/additive manufacturing) }\end{array}$ & $13.1 \%$ \\
\hline Total cost of ownership & $11.8 \%$ \\
\hline $\begin{array}{l}\text { Vicinity to engineering \& production + company } \\
\text { strategies focused on product and process } \\
\text { innovations }\end{array}$ & $7.9 \%$ \\
\hline $\begin{array}{l}\text { Increasing labour cost in the host country (including } \\
\text { higher productivity in the home country) }\end{array}$ & $7.6 \%$ \\
\hline Organisational flexibility & $7.4 \%$ \\
\hline $\begin{array}{l}\text { Cost and difficulties in controlling the host country } \\
\text { activities }\end{array}$ & $6.8 \%$ \\
\hline Government incentives (in the home country) & $5.8 \%$ \\
\hline $\begin{array}{l}\text { Poor company performance and global financial and } \\
\text { economic crisis }\end{array}$ & $5.8 \%$ \\
\hline $\begin{array}{l}\text { Availability of research centres and universities in } \\
\text { the home country }\end{array}$ & $4.8 \%$ \\
\hline $\begin{array}{l}\text { Availability of production capacity in the home } \\
\text { country }\end{array}$ & $4.5 \%$ \\
\hline $\begin{array}{l}\text { Host country employees' low skills and 'work } \\
\text { attitude' }\end{array}$ & $4.4 \%$ \\
\hline $\begin{array}{l}\text { Minimum order quantity (including difficulties in } \\
\text { forecasting sales volumes) }\end{array}$ & $4.3 \%$ \\
\hline $\begin{array}{l}\text { Intellectual property issues } \quad \text { (including } \\
\text { counterfeiting) }\end{array}$ & $3.4 \%$ \\
\hline $\begin{array}{l}\text { Entrepreneurs' emotional attachment to the home } \\
\text { country }\end{array}$ & $2.5 \%$ \\
\hline $\begin{array}{l}\text { Supply chain risks (different from exchange rate } \\
\text { fluctuations) }\end{array}$ & $2.2 \%$ \\
\hline Poor attractiveness of host country & $2.2 \%$ \\
\hline $\begin{array}{l}\text { Social pressure in the home country (e.g. trade } \\
\text { unions) }\end{array}$ & $2.2 \%$ \\
\hline Duties and tariffs & $1.8 \%$ \\
\hline Physical distance & $1.6 \%$ \\
\hline Availability of suppliers in the home country & $1.2 \%$ \\
\hline Carbon footprint and other environmental issues & $1.0 \%$ \\
\hline Exchange rate risk & $1.0 \%$ \\
\hline $\begin{array}{l}\text { Corporate social responsibility (e.g. with respect to } \\
\text { work conditions in the host country) (this does not } \\
\text { include environmental issues) }\end{array}$ & $0.7 \%$ \\
\hline Adoption of 3D printing/additive manufacturing & $0.5 \%$ \\
\hline Energy Costs & $0.1 \%$ \\
\hline
\end{tabular}


Table 6. Back-shoring motivations cited jointly with production automation Only 10 most cited motivations. Source: UMRD.

\begin{tabular}{lc}
\hline \multicolumn{1}{c}{ Motivations } & Decisions \\
\hline Cost and difficulties in controlling the host country activities & $21.8 \%$ \\
Made in effect (home country) & $18.9 \%$ \\
Delivery time (including delays) & $18.4 \%$ \\
Vicinity of engineering \& production + company strategies & $17.2 \%$ \\
focused on product and process innovations & $13.7 \%$ \\
Off-shored poor product quality & $12.9 \%$ \\
Customer responsiveness/vicinity - higher service quality & $12.9 \%$ \\
Increasing labour cost in the host country (including higher & $12.5 \%$ \\
productivity in the home country) & $9.1 \%$ \\
Total cost of ownership & $8.3 \%$ \\
\hline Company's organisational restructuring & \\
\hline
\end{tabular}

Focusing attention on individual Industry 4.0 technologies, it is clear that production automation and additive manufacturing are the only two factors specifically cited by back-shoring companies. This finding is consistent with the previous statement by [11] and the results obtained by analysing the extant literature. However, while automation has been declared as a back-shoring driver in $13.1 \%$ of the sampled decisions, the adoption of additive manufacturing technologies has been considered as a reshoring motivation in only $0.5 \%$ of the sampled relocation decisions.

It is important to note that, while [10] and [11] suggested that the adoption of production automation is more consistent with 'cost-oriented' and 'flexibility-oriented' back-shoring decisions, our data shows that such technology has been cited jointly with drivers belonging to quality oriented relocation decisions. More specifically, the adoption of the investigated technology was coupled with the 'Cost and difficulties in controlling the host country activities', the 'Made in effect' and the 'Delivery time' (Table 6).

Further insights regarding the role of production automaton emerge when considering contingency factors. Among them, the breakdown by company size unexpectedly shows this technology, which generally requires high levels of investment, is adopted primarily by medium-sized companies (18.2\% of total companies in the size range) and small/micro companies $(12.2 \%)$ rather than large ones $(11.5 \%)$ (Table 7$)$.

When considering the geographic contingencies (Table 8), data clearly shows that the adoption of automated production technologies is not influenced by the host region in which companies have previously off-shored their production activities. This finding is partially unexpected, since one would have expected that back-shoring decisions regarding production activities located in low-cost countries (e.g. Asia) would be largely supported by automation when compared with medium- and high-cost countries (e.g. Europe). Moreover, it is in contrast with

Table 7. Back-shoring evidence citing production automation: breakdown by company size. Source: UMRD

\begin{tabular}{lc}
\hline \multicolumn{1}{c}{ Company size } & Decisions \\
\hline Large & $11.5 \%$ \\
Medium & $18.2 \%$ \\
Small \& micro & $12.2 \%$ \\
Not available & - \\
Total & $13.1 \%$ \\
\hline
\end{tabular}

Table 8. Back-shoring evidence citing production automation: breakdown by host region. Source: UMRD

\begin{tabular}{lc}
\hline \multicolumn{1}{c}{ Host region } & Decisions \\
\hline Asia & $13.6 \%$ \\
Europe \& former USSR & $12.8 \%$ \\
Africa & $21.2 \%$ \\
Americas & $3.2 \%$ \\
Oceania & - \\
Not available & $13.6 \%$ \\
Total & $13.1 \%$ \\
\hline
\end{tabular}

the findings of [23] in terms of the higher 'Industry 4.0 readiness' of large companies with respect to small and medium ones. A possible explanation for this unexpected result may be represented by the latter-day implementation of automated production systems by medium-sized companies.

Given that there is little evidence of back-shoring companies implementing 3D/additive manufacturing technologies, further characterisation of this technology is not relevant.

\section{CONCLUDING REMARKS}

This paper aimed to investigate the relationship (if any) between Industry 4.0 technologies and decisions to relocate previously off-shored manufacturing activities to the home country. To shed new light on this research question, an exploratory approach has been implemented adopting a two-step methodology. First, a structured literature review was conducted on a sample of 115 Scopus-indexed journal articles published between 2007 and August 2019. This research clearly shows the topic is attracting a growing interest among scholars (at least since 2014). However, they have focused primarily on specific technologies, namely production automation and 3D printing/additive manufacturing, and the findings that have emerged are still not sufficiently conclusive. Only four journal articles specifically address the relationship between Industry 4.0 technologies and back-shoring decisions; moreover, their findings are somewhat different. For instance, [23] found a significant and positive relationship (but not also the causality) between the two, while [11] and [35] did not discover any connection. This finding might suggest that country-specific issues may have influenced the results, since [23] have focused on German, Austrian and Swiss companies, while [35] on Danish ones.

As clearly demonstrated by the data from the UMRD, the European companies that back-shored their production based on Industry 4.0 technologies are characterised by a lack of similarity, especially in terms of industry and adopted technology (production automation vs additive manufacturing).

Another issue emerging as relevant is the one concerning size. While it is generally expected that Industry 4.0 technologies would be more readily adopted by large companies, an analysis of the UMRD data provides evidence that, at least for production automation, it is primarily medium-sized companies that have adopted them (Table 7). Future research should further address this aspect, given the implications for policymakers.

A third question is still open as regards the relationships (if any) between the adoption of a specific Industry 4.0 technology and the strategic aims pursued by the back-shoring decision. While [11] and [10] suggest that production automation is more consistent with 'cost-oriented' and 'flexibility-oriented' back- 
shoring decisions, data from the UMRD provides evidence that companies adopting this technology have been driven by motivations linked to the 'quality-oriented' back-shoring decisions.

Support for the adoption of Industry 4.0 technologies can be given to companies by policymakers that should not only offer companies the possibility of reducing the fixed costs related to the adoption of Industry 4.0 technologies but also to develop 'the necessary digital competencies for the successful exploitation of these technologies' [11]. In this respect, [10] point out that such digital competences may also substitute for the manual skills no longer available in Western countries, given the deindustrialisation resulting from decades of manufacturing offshoring.

The previous discussion leads us to conclude that further studies are required to investigate the proposed research question. Our study has an explorative aim and is mainly based on secondary data; therefore, our conclusions are not generalisable. However, it may represent a useful summary of the academic debate and of back-shoring evidence that has been available up until now. In this respect, we suggest future research should couple a longitudinal case study approach with quantitative surveys. Moreover, this study offers some useful insights for policymakers since it clearly shows that Industry 4.0 technologies may support the back-shoring phenomenon. Therefore, industrial policy aiming to support the diffusion of such disruptive technologies (e.g. 'Industrie 4.0' in Germany, 'HVM Catapult' in the UK, 'Industrie du Futur' in France and 'Piano Nazionale Industria 4.0' in Italy) might also have a positive effect in terms of companies implementing production relocations to their home country. Finally, this article provides support for managers of manufacturing companies by enabling them to better evaluate the benefits that Industry 4.0 technologies may offer back-shoring strategies.

\section{REFERENCES}

[1] S. Manning, Mitigate, tolerate or relocate? Offshoring challenges, strategic imperatives and resource constraints, Journal of World Business 49 (2014), pp. 522-535.

DOI: https://doi.org/10.1016/j.jwb.2013.12.006

[2] P. Barbieri, S. Elia, L. Fratocchi, R. Golini, Relocation of second degree: moving towards a new place or returning home?, Journal of Purchasing and Supply Management 25 (2019), 100525. DOI: https://doi.org/10.1016/j.pursup.2018.12.003

[3] L. Fratocchi, C. Di Mauro, P. Barbieri, G. Nassimbeni, A. Zanoni, When manufacturing moves back: concepts and questions, Journal of Purchasing and Supply Management 20 (2014), pp. 54-59.

DOI: https://doi.org/10.1016/i.pursup.2014.01.004

[4] L. Fratocchi, A. Ancarani, P. Barbieri, C. Di Mauro, G. Nassimbeni, M. Sartor, M. Vignoli, A. Zanoni, Manufacturing back-reshoring as a nonlinear internationalization process, in: The Future of Global Organizing, Progress in International Business Research (PIBR). R. Van Tulder, A. Verbeke, R. Drogendijk (editors). Emerald, Bingley, 2015, ISBN 978-1-78560-423-2, pp. 367-405.

[5] L. M. Ellram, W. L. Tate, K. J. Petersen, Offshoring and reshoring: an update on the manufacturing location decision, Journal of Supply Chain Management 49 (2013), pp.14-22. DOI: https://doi.org/10.1111/iscm.12019

[6] J. V. Gray, K. Skowronski, G. Esenduran, M. J. Rungtudanatham, The reshoring phenomenon: what supply chain academics ought to know and should do, Journal of Supply Chain Management 49 (2013), pp. 27-33.

DOI: https://doi.org/10.1111/jscm.12012
[7] P. Barbieri, F. Ciabuschi, L. Fratocchi, M. Vignoli, What do we know about manufacturing reshoring?, Journal of Global Operations and Strategic Sourcing 11 (2018), pp. 79-122. DOI: https://doi.org/10.1108/JGOSS-02-2017-0004

[8] B. Wiesmann, J. R. Snoei, P. Hilletofth, D. Eriksson, Drivers and barriers to reshoring: a literature review on offshoring in reverse, European Business Review 29 (2017), pp. 15-42. DOI: https://doi.org/10.1108/EBR-03-2016-0050

[9] J. Stentoft, J. Olhager, J. Heikkilä, L. Thoms, Manufacturing backshoring: a systematic literature review, Operations Management Research 9 (2016), pp. 53-61.

DOI: https://doi.org/10.1007/s12063-016-0111-2

[10] A. Ancarani, C. Di Mauro, Reshoring and Industry 4.0: how often do they go together?, IEEE Engineering Management Review 46 (2018), pp. 87-96.

DOI: https://doi.org/10.1109/EMR.2018.2833475

[11] A. Ancarani, C. Di Mauro, F. Mascali, Backshoring strategy and the adoption of Industry 4.0: evidence from Europe, Journal of World Business 54 (2019), pp. 360-371.

DOI: https://doi.org/10.1016/i.jwb.2019.04.003

[12] L. Fratocchi, Additive manufacturing technologies as a reshoring enabler: a why, where and how approach. World Review of Intermodal Transportation Research 7 (2018), pp. 264-293. DOI: https://doi.org/10.1504/WRITR.2018.093565

[13] L. Fratocchi, Additive manufacturing as a reshoring enabler: considerations on the why issue, Proc. of the Workshop on Metrology for Industry 4.0 and IoT, MetroInd 4.0 and IoT, Brescia, Italy, 16-18 April 2018, Article number 8428316. DOI: https://doi.org/10.1109/METROI4.2018.8428316

[14] H. Moradlou, W. Tate, Reshoring and additive manufacturing, World Review of Intermodal Transportation Research 7 (2018), pp. $241-263$

DOI: https://doi.org/10.1504/WRITR.2018.093564

[15] H. Kagermann, W. Wahlster, J. Helbig, Recommendations for implementing the strategic initiative INDUSTRIE 4.0: securing the future of German manufacturing industry, Final Report of the Industrie 4.0 Working Group, Acatech - Deutsche Akademie der Technikwissenschaften e.V., Berlin, 2013.

[16] J. Alcácer, J. Cantwell, L. Piscitello, Internationalization in the information age: a new era for places, firms, and international business networks?, Journal of International Business Studies 47 (2016), pp. 499-512.

DOI: https://doi.org/10.1057/jibs.2016.22

[17] W. Chen, F. Kamal, The impact of information and communication technology adoption on multinational firm boundary decisions, Journal of International Business Studies 47 (2016), pp. 563-576.

DOI: https://doi.org/10.1057/jibs.2016.6

[18] E. E. Leamer, M. Storpe, The economic geography of the Internet age, Journal of International Business Studies 32 (2001), pp. 641-665.

DOI: https://doi.org/10.1057/palgrave.jibs. 84909988

[19] P. J. Buckley, International integration and coordination in the global factory, Management International Review 51 (2011), pp. 269-283.

DOI: https://doi.org/10.1007/s11575-011-0075-2

[20] P. J. Buckley, P. N. Ghauri, Globalisation, economic geography and the strategy of multinational enterprises, Journal of International Business Studies 35 (2004), pp. 81-98. DOI: https://doi.org/10.1057/palgrave.jibs.8400076

[21] E. Brynjolfsson, A. McAfee, The Second Machine Age: Work, progress, and prosperity in a time of brilliant technologies. Norton Publishers, New York, 2014, ISBN 0393350649.

[22] M. Ketokivi, V. Turkulainen, T. Seppälä, P. Rouvinen, J. AliYrkkö, Why locate manufacturing in a high-cost country? A case study of 35 production location decisions, Journal of Operations Management 49 (2017), pp. 20-30.

DOI: https://doi.org/10.1016/i.jom.2016.12.005

[23] B. Dachs, S. Kinkel, A. Jäger, Bringing it all back home? Backshoring of manufacturing activities and the adoption of 
Industry 4.0 technologies, Journal of World Business 54 (2019) 101017.

DOI: https://doi.org/10.1016/i.jwb.2019.101017

[24] H. Moradlou, C. J. Backhouse, R. Ranganathan, Responsiveness, the primary reason behind re-shoring manufacturing activities to the UK: an Indian industry perspective, International Journal of Physical Distribution \& Logistics Management 47 (2017), pp. 222236.

DOI: https://doi.org/10.1108/IJPDLM-06-2015-0149

[25] L. Bals, J. F. Kirchoff, K. Foerstl, Exploring the reshoring and insourcing decision making process: toward an agenda for future research, Operations Management Research 9 (2016), pp. 1-15. DOI: https://doi.org/10.1007/s12063-016-0113-0

[26] G. Engström, P. Hilletofth, D. Eriksson, K. Sollander, Drivers and barriers of reshoring in the Swedish manufacturing industry, World Review of Intermodal Transportation Research 7 (2018), pp. 195-220.

DOI: https://doi.org/10.1504/WRITR.2018.093550

[27] L. Fratocchi, A. Ancarani, P. Barbieri, C. Di Mauro, G. Nassimbeni, M. Sartor, M. Vignoli, A. Zanoni, Motivations of manufacturing back-reshoring: an interpretative framework, International Journal of Physical Distribution \& Logistics Management 46 (2016), pp. 98-127.

DOI: https://doi.org/10.1108/IJPDLM-06-2014-0131

[28] G. Engström, K. Sollander, P. Hilletofth, D. Eriksson, Reshoring drivers and barriers in the Swedish manufacturing industry, Journal of Global Operations and Strategic Sourcing 11(2) (2018), pp. 174-201.

DOI: https://doi.org/10.1108/JGOSS-06-2017-0014

[29] A. Ancarani, C. Di Mauro, L. Fratocchi, G. Orzes, M. Sartor, Prior to reshoring: a duration analysis of foreign manufacturing ventures, International Journal of Production Economics 169 (2015), pp.141-155.

DOI: https://doi.org/10.1016/i.ipe.2015.07.031

[30] L. Wan, G. Orzes, M. Sartor, G. Nassimbeni, Reshoring: does home country matter?, Journal of Purchasing and Supply Management 25 (2019), 100551.

DOI: https://doi.org/10.1016/i.pursup.2019.100551

[31] L. Wan, G. Orzes, M. Sartor, C. Di Mauro, G. Nassimbeni, Entry modes in reshoring strategies: an empirical analysis, Journal of Purchasing and Supply Management 25 (2019), 100522. DOI: https://doi.org/10.1016/j.pursup.2018.11.002

[32] A. Fink, Conducting Research Literature Reviews: From the Internet to Paper, Sage Publications, London, 2005, ISBN 1412971896.

[33] S. Seuring, S. Gold, Conducting content-analysis based literature reviews in supply chain management, Supply Chain Management: An International Journal 17 (2012), pp. 544-555. DOI: https://doi.org/10.1108/13598541211258609

[34] M. Greenwood, Which business and management journal database is best?, 2011. Online [Accessed 22 December 2018] https://bizlib247.wordpress.com/2011/06/19/which-businessand-management-journal-database-is-best/

[35] J. Stentoft, C. Rajkumar, Balancing theoretical and practical relevance in supply chain management research, International Journal of Physical Distribution \& Logistics Management 48 (2018), pp. 504-523.

DOI: https://doi.org/10.1108/IJPDLM-01-2018-0020

[36] J. S. Arlbjørn, O. S. Mikkelsen, Backshoring manufacturing: notes on an important but under-researched theme, Journal of Purchasing \& Supply Management 20 (2014), pp. 60-62. DOI: https://doi.org/10.1016/i.pursup.2014.02.003

[37] J. Heikkilä, M. Martinsuo, S. Nenonen, Backshoring of production in the context of a small and open Nordic economy, Journal of Manufacturing Technology Management 29 (2018), pp. 658-675.

DOI: https://doi.org/10.1108/JMTM-12-2016-0178

[38] J. Heikkilä, S. Nenonen, J. Olhager, J. Stentoft, Manufacturing relocation abroad and back: empirical evidence from the Nordic countries, World Review of Intermodal Transportation Research
7 (2018)

DOI: https://doi.org/10.1504/WRITR.2018.10014279

[39] M. Johansson, J. Olhager, Manufacturing relocation through offshoring and backshoring: the case of Sweden, Journal of Manufacturing Technology Management 29 (2018), pp. 637-657. DOI: https://doi.org/10.1108/JMTM-01-2017-0006

[40] M. Johansson, J. Olhager, Comparing offshoring and backshoring: the role of manufacturing site location factors and their impact on post-relocation performance, International Journal of Production Economics 205 (2018), pp. 37-46. DOI: https://doi.org/10.1016/j.ijpe.2018.08.027

[41] K. De Backer, T. DeStefano, C. Menon, J. R. Suh, Industrial robotics and the global organisation of production, OECD Science, Technology and Industry, Paris, France, 2018, Working Papers 2018/03.

DOI: https://doi.org/10.1787/dd98ff58-en

[42] M. H. Abbasi, It's not offshoring or reshoring but right-shoring that matters, Journal of Textile and Apparel, Technology and Management 10 (2016), pp. 1-6. Online [accessed 04 December 2020]

https://ojs.cnr.ncsu.edu/index.php/JTATM/article/viewFile/9 $\underline{847 / 4920}$

[43] Y. Lu, Industry 4.0: a survey on technologies, applications and open research issues, Journal of Industrial Information Integration 6 (2017), pp. 1-10.

DOI: https://doi.org/10.1016/i.jii.2017.04.005

[44] M. Bettiol, C. Burlina, M. Chiarvesio, S. Micelli, Manufacturing, where art thou? Value chain organization and cluster-firm strategies between local and global, in: Local Clusters in Global Value Chains. V. De Marchi, E. De Maria, G. Gereffi (editors). Routledge, London, 2018, ISBN 1138742864, pp 155-174. DOI: https://doi.org/10.4324/9781315182049

[45] L. Brennan, K. Ferdows, J. Godsell R. Golini, R. Keegan, S. Kinkel, J. Srai, M. Taylor, Manufacturing in the world: where next?, International Journal of Operations \& Production Management 35 (2015), pp. 1253-1274.

DOI: https://doi.org/10.1108/IJOPM-03-2015-0135

[46] R. Strange, A. Zucchella, Industry 4.0, global value chains and international business, Multinational Business Review 25 (2018), pp. 174-184.

DOI: https://doi.org/10.1108/MBR-05-2017-0028

[47] R. d'Aveni, The 3-D printing revolution, Harvard Business Review 93 (2015), pp. 40-48. Online [Accessed 04 December 2020] https://hbr.org/2018/07/the-3-d-printing-playbook

[48] A. O. Laplume, B. Petersen, J. M. Pearce, Global value chains from a 3D printing perspective, Journal of International Business Studies 47 (2016), pp. 595-609. DOI: https://doi.org/10.1057/jibs.2015.47

[49] J. Müller, V. Dotzauer, K. I. Voigt, Industry 4.0 and its impact on reshoring decisions of German manufacturing enterprises, in: Supply Management Research. C. Bode, R. Bogaschewsky, M. Eßig, R. Lasch, W. Stölzle (editors). Springer, Heidelberg, 2017, ISBN 978-3-658-18632-6, pp. 165-179.

DOI: https://doi.org/10.1007/978-3-658-18632-6 8

[50] F. Fel, E. Griette, Near-reshoring your supplies from China: a good deal for financial motives too, Strategic Direction 33 (2017), pp. 24-16.

DOI: https://doi.org/10.1108/SD-11-2016-0150

[51] S. Kinkel, Future and impact of backshoring - some conclusions from 15 years of research on German practices, Journal of Purchasing and Supply Management 20 (2014), pp. 63-65 DOI: https://doi.org/10.1016/i.pursup.2014.01.005

[52] S. Kinkel, S. Maloca, Drivers and antecedents of manufacturing offshoring and backshoring - a German perspective, Journal of Purchasing and Supply Management 15 (2009), pp. 154-165. DOI: https://doi.org/10.1016/j.pursup.2009.05.007 